\title{
Effect of Pre harvest Spray of ZnSO4, KNO3 and NAA on Growth, Yield and Quality of Ber (Zizyphus mauritiana Lamk.) cv. Seb under Malwa Plateau Conditions
}

\author{
J. Gami*, P. Sonkar, A. Haldar and D.K. Patidar \\ RVSKVV, College of Horticulture, Mandsaur (M.P.) - 458001, India \\ *Corresponding author
}

Keywords

Pre harvest spray, cv. Seb, Zizyphus, and Malwa Plateau

Article Info

Accepted:

15 February 2019

Available Online:

10 March 2019
A B S T R A C T

The experiment was conducted at the Instructional cum Research Fruit Orchard, College of Horticulture, Mandsaur (M.P.), Department of Fruit Science, Rajmata Vijayaraje Scindia Krishi Vishwa Vidyalaya, Gwalior (M.P.). The experiment comprised 13 treatments of foliar spray of $\mathrm{ZnSO}_{4}, \mathrm{KNO}_{3}$ and NAA and control, first foliar spray of growth regulator and micronutrient $\left(\mathrm{ZnSO}_{4}\right.$ and $\left.\mathrm{KNO}_{3}\right)$ on crop was done on $15^{\text {th }}$ October, 2014 and same spray was repeated after 30 days of the first spray with three replications and data analyzed in Randomized Block Design (RBD). The treatments which were compared among them and found best during the period of experiment are given below: Growth Parameters: Maximum Shoot diameter $(9.32 \mathrm{~mm})$, Shoot length $(204 \mathrm{~cm})$, Physical parameters: Maximum Fruit length $(3.17 \mathrm{~cm})$, Fruit diameter $(3.00 \mathrm{~cm})$, Fruit volume $(23.50 \mathrm{ml})$, Stone weight $(1.70 \mathrm{~g})$, Pulp weight $(20.67 \mathrm{~g})$, Specific gravity (0.97), Bio - chemical parameters: Maximum TSS (15.93 ${ }^{0}$ Brix $)$, minimum Acidity $(0.26 \%)$, Ascorbic acid $(49.47 \mathrm{mg} / 100 \mathrm{~g}$ of pulp), Reducing sugar $(6.11 \%)$, Total sugars $(11.87 \%)$, Non-reducing sugar (5.76\%) and Yield parameters: Maximum Number (1608.33) of fruits / tree, Fruit weight $(22.87 \mathrm{~g})$, Yield / tree $(36.79 \mathrm{~kg})$ was found in treatment $\mathrm{T}_{12}$ (NAA 60 $\left.\mathrm{ppm}+\mathrm{KNO}_{3} 1.5 \%+\mathrm{ZnSO}_{4} 0.5 \%\right)$ and minimum was found in control respectively.

\section{Introduction}

Ber (Zizyphus mauritiana Lamk.) the member of family Rhamnaceae, is one of the ancient fruit. Ber is a very nutritious fruit and is rich in vitamin $\mathrm{C}, \mathrm{A} \& \mathrm{~B}$ complex. Fresh ber fruit contains moisture (81.6-83.0 g), total sugars (5.4-10.5g), reducing sugar (1.4-6.2g), non reducing sugar $(3.2-8.0 \mathrm{~g})$, iron $(0.76-1.8 \mathrm{mg})$, Morton 1987. NAA is an important growth regulator of auxin group, which helps to reduce fruit drop and to improve fruit set and quality specially TSS. NAA spray was useful in increasing fruit yield and quality (Singh and Randhawa, 2001). They act as a metabolic sink for the diversion of metabolic from one part to other of the plant specially towards developing fruits. The pre harvest sprays of PGR's are using to control fruit drop and to improve fruits retention percentage. Zinc also considered necessary for the growth and development of fruits. It is one of the essential 
element for the formation of chlorophyll and hence useful towards photosynthetic activity. Zinc is a constituent of some enzymes and takes part in the synthesis of Indole Acetic Acid in plants.

Potassium is an important nutrient for plant meristematic growth and physiological functions, including regulation of water and gas exchange in plants, protein synthesis, enzyme activation, and photosynthesis and carbohydrate translocation in plants.

Materials and Methods
The experiment was conducted at the Instructional cum Research Fruit Orchard, College of Horticulture, Mandsaur (M.P.), Department of Fruit Science, Rajmata Vijayaraje Scindia Krishi Vishwa Vidyalaya, Gwalior (M.P.). The experiment comprised 13 treatments of foliar spray of $\mathrm{ZnSO}_{4}, \mathrm{KNO}_{3}$ and NAA and control, first foliar spray of growth regulator and micronutrient $\left(\mathrm{ZnSO}_{4}\right.$ and $\mathrm{KNO}_{3}$ ) on crop was done on $15^{\text {th }}$ October, 2014 and same spray was repeated after 30 days of the first spray with three replications and the analysis of variance for Randomized Block Design.

Titer $\times$ Normality of $\mathrm{NaOH} \times$ Volume made up $\times$

Acidity $(\%)=$

Eq.wt.of acid $\times 100$

Volume of sample taken for estimation $\times$ Wt. of

Sample taken $\times 1000$

\section{TSS/acid ratio = Total Soluble Solids / Acidity}

Ascorbic acid $=$ (mg / 100 g pulp)
Titre $x$ dye factor $x$ volume made up

Aliquot extract taken for estimation $x \times 100$
weight of sample taken for estimation

\section{Results and Discussion}

\section{Growth parameters}

Results showed the maximum shoot diameter $(9.32 \mathrm{~mm})$ and Shoot length $(204.00 \mathrm{~cm})$ observed with the application of $\mathrm{T}_{12}$ (NAA 60 $\mathrm{ppm}+\mathrm{KNO}_{3} 1.5 \%+\mathrm{ZnSO}_{4} 0.5 \%$ ) which was significantly superior than other treatment. The possible reason for enhancement of shoot length and diameter with NAA, potassium nitrate and zinc sulphate might be due to their involvement in hormonal metabolism, increased cell division, elongation and expansion of cells so finaly increasing vegetative growth. These results are in accordance with Yadav and Chaturvedi (2004) in ber cv. Banarsi Karaka. Similar results have also been reported by Kale et al., (2000), Jain and Dsahora (2007), Sarolia et al., (2007) and Lal and Dhaka (2003). The results are in accordance with the findings of by Iqbal et al., (2009), Singh (1988) and Rathore (1975) in guava (Table 1).

\section{Physical parameters}

The physical characteristics of fruit are an expression of a plant's vegetative activity which was also significantly influenced by $\mathrm{NAA}, \mathrm{ZnSO}_{4}$ and $\mathrm{KNO}_{3}$. Result showed that largest fruit length $(3.17 \mathrm{~cm})$ and fruit diameter $(3.00 \mathrm{~cm})$, volume of fruit $(23.50$ $\mathrm{ml})$, and stone weight ( $1.70 \mathrm{~g})$ was found with the application of $\mathrm{T}_{12}$ (NAA $60 \mathrm{ppm}+\mathrm{KNO}_{3}$ $+\mathrm{ZnSO}_{4}$ 0.5\%), pulp weight (20.90 g) was found with the application of $\mathrm{T}_{11}$ (NAA 40 $\mathrm{ppm}+\mathrm{KNO}_{3} 1.0 \%+\mathrm{ZnSO}_{4} 0.5 \%$ ) where 
significantly superior over the rest of the treatment. The increase in fruit length and fruit diameter by the application of $\mathrm{NAA}, \mathrm{KNO}_{3}$ and $\mathrm{ZnSO}_{4}$ might be due to optimum supply of plant nutrients and growth hormones in right amount during the entire crop growth period causing vigorous vegetative development of the plants and ultimately production of more photosynthates.

This increase in fruit length and diameter can be attributed to the involvement of NAA in cell division, cell expansion and increased volume of inter-cellular spaces in the mesocarpic cells. The application of NAA might have a role in increasing the auxin level of fruits which, in turn, might have helped in the development of fruit components as there is direct correlation between auxin content and fruit growth. The improved fruit during observation by plant growth regulators has also been reported by Singh et al., (1959) in mango, Singh (1973), Grewal et al., (1993), Kale et al., (2000) and Yadav (2002) in ber fruits. Increase in fruit size has been recorded with the help of the NAA in different fruits like guava, Barche et al., 2007 and (Pandey, 1999) in Ber.

It could also be due to higher mobilization of food and minerals from other parts of the plant towards the developing fruits that are extremely active metabolic sink, secondly, increase in weight and size might be due to foliar feeding of nutrients resulting in rapid fruit development. The spray of NAA might have raised the auxin level in fruit which ultimately helped in the development of its various components as there is a direct corelation between auxin content and fruit growth in several plants. Similar results have also been reported by Singh et al., (2001), Kale et al., (1999) and Bankar and Prasad (1990) in ber. The application of $\mathrm{ZnSO}_{4}$ also caused significant increase in fruit volume of ber which can be attributed to the reason that zinc is involved in the synthesis of tryptophan, a precursor of auxin. Thus application of zinc incremented auxin concentration which ultimately increases fruit volume by the same procedure as explained above. $\mathrm{ZnSO}_{4}$ also promotes the absorption of water and prevents stunting in plants. It's regulates the semipermeability of cell wall by which more water is mobilized into fruits, which result in maximum fruit diameter. Similar increase in fruit size was also noted by (Prakash and Balakrishnan, 2014), potassium as an essential element increasing fruit enlargement and cell turgidity by reducing carbohydrate contents.

The enhancement of fruit characteristics such as weight, fruit length, fruit diameter and volume are due to different roles of zinc and potassium in plant physiological processes. Applying zinc to the trees improved fruit quality by enhancing the formation and translocation of carbohydrates and carbohydrate enzymes. Zinc has key roles in chlorophyll, protein and DNA synthesis in plants. (Ramezani and Shekafandeh, 2011).

The possible reason for enhancement of fruit size with $\mathrm{NAA}, \mathrm{KNO}_{3}$ and $\mathrm{ZnSO}_{4}$ might be due to their involvement in hormonal metabolism, increased cell division, elongation and expansion of cells. These results are in accordance with Bal et al., (1984), Kale et al., (2000), Bhati and yadav (2003) in ber cv. Gola. Yadav and Chaturvedi (2004) in ber cv. Banarsi Karaka.

The possible reasons for enhancement in fruit size, weight, pulp weight and stone weight with NAA, $\mathrm{KNO}_{3}$ and $\mathrm{ZnSO}_{4}$ might be due to higher synthesis of metabolites and enhanced mobilization of food and minerals from other parts of the plants towards the developing fruits as it is a well established fact that the fruit acts as extremely active metabolic sink. It might have also been due to the involvement of these chemicals in cell division, cell 
expansion, increased volume of intercellular space in the mesocarpic cells and increased absorption of water and mobilization of sugars and minerals in the expanded cells and intercellular space of the mesocarp. These results are in close proximity with the findings of Kale et al., (2000), Singh and Randhawa (2001) and Rathore and Chandra (2002) in ber.

\section{Bio-chemical parameters}

Application of plant NAA, $\mathrm{ZnSO}_{4}$ and $\mathrm{KNO}_{3}$ not only increased the yield but also improved the fruit quality. Their application significantly influenced the bio-chemical constituent's viz. acidity, TSS, reducing, nonreducing and total sugars, TSS/acid ratio and ascorbic acid of the fruit over the control. The minimum acidity $(0.26 \%)$ and maximum TSS/acid ratio (61.06), total soluble solids $\left(15.93{ }^{0}\right.$ Brix $)$, ascorbic acid $(49.47 \mathrm{mg} / 100 \mathrm{~g})$ total sugars $(11.87 \%)$, reducing sugar $(6.11 \%)$ and non-reducing sugar $(5.76 \%)$ were obtained with the application of $\mathrm{T}_{12}$ (NAA 60 $\mathrm{ppm}+\mathrm{KNO}_{3}+\mathrm{ZnSO}_{4}$ 0.5\%) which were significantly superior among the remaining treatment. The NAA, $\mathrm{KNO}_{3}$ and $\mathrm{ZnSO}_{4}$ decrease the acidity of fruits. It appears that acids under the influence of growth regulators might have either fastly been converted into sugars and their derivatives by reactions involving reverse glycollytic pathways or might have been used in respiration or both. The data clearly indicated that the combination of (NAA $60 \mathrm{ppm}+\mathrm{KNO}_{3}+$ $\mathrm{ZnSO}_{4} \quad 0.5 \%$ ) registered minimum acidity. Same trend has also been observed by Bal et al., (1984) in ber, Kher et al., (2005) in guava. This decrease in acidity content of fruits might be due to increase in TSS and total sugars. The acids under the influence of chemicals might have either been converted in to sugars and their derivatives by the reactions involving reversal of glycolytic pathway or may be have been used as a substrate in the respiration or both. The result is in agreement with the findings of Kunda and Mitra (1999) in guava.

The increase in TSS of treated fruit juice might be due to the increase in mobilization of carbohydrates from the source to sink (fruits) by auxin. This may be attributed to the fact that application of NAA might have increased a'-amylase activity and thus there was conversion of starch into sugars and hence improved total soluble solids content. This increase in TSS and total sugar with the combined application NAA, and Zinc sulphate, might be due to the facts that Zinc and NAA helpful in the process of photosynthesis which leads to the accumulations of oligosaccharides and polysaccharides in higher amount besides this also regulators the enzymatic activity and the enzymes that metabolize the carbohydrates into simple sugars. The increase in TSS and TSS: acid ratio with $\mathrm{KNO}_{3}$ treatment could be attributed to the enhanced photosynthetic efficiency of the leaves (Singh et al., 1982) and a possible increase in translocation of assimilates into the fruits. These results are agreement with the findings of Bankar and Prasad (1990), Masalkar and Wavhal (1991), Grewal et al., (1993), Kale et al., (1999), Bal and Randhawa (2007) and Bhati and Yadav (2003) in ber.

In the present investigation, it was observed that fruits treated with various levels of NAA, $\mathrm{KNO}_{3}$ and $\mathrm{ZnSO}_{4}$ influenced all type of sugars i.e. total sugars, reducing sugar and nonreducing sugar. The possible reason might be that the growth regulators promoted hydrolysis of starch into sugars or reduced competition between the fruits for metabolites. This increase in fruit sweetness with potassium sprays might be due to increased photosynthetic activity and building of more carbohydrates and its transport to fruits. 
Table.1 Effect of pre-harvest spray of $\mathrm{NAA}, \mathrm{KNO}_{3}$ and $\mathrm{ZnSO}_{4}$ on growth attributes in ber

\begin{tabular}{|c|c|c|c|c|c|c|c|c|}
\hline Treatments & $\begin{array}{c}\text { Shoot Length } \\
(\mathrm{cm})\end{array}$ & $\begin{array}{c}\text { Fruit Length } \\
(\mathbf{m m})\end{array}$ & $\begin{array}{c}\text { Fruit Diameter } \\
\text { (cm) }\end{array}$ & $\begin{array}{c}\text { Shoot Diameter } \\
(\mathbf{m m})\end{array}$ & $\begin{array}{c}\text { Fruit volume } \\
(\mathbf{m l})\end{array}$ & Specific gravity & Pulp weight (g) & Stone weight (g) \\
\hline $\mathbf{T}_{0}$ & 146.67 & 2.67 & 2.42 & 6.97 & 18.77 & 0.91 & 15.87 & 1.27 \\
\hline$T_{1}$ & 164.67 & 2.80 & 2.73 & 7.93 & 21.07 & 0.88 & 17.27 & 1.30 \\
\hline $\mathbf{T}_{2}$ & 178.00 & 2.94 & 2.85 & 8.30 & 22.10 & 0.95 & 19.70 & 1.40 \\
\hline $\mathbf{T}_{\mathbf{3}}$ & 194.00 & 2.90 & 2.87 & 8.36 & 22.37 & 0.96 & 19.97 & 1.43 \\
\hline $\mathbf{T}_{4}$ & 170.67 & 2.81 & 2.69 & 7.60 & 20.40 & 0.93 & 17.50 & 1.37 \\
\hline $\mathbf{T}_{5}$ & 179.00 & 2.84 & 2.65 & 8.00 & 21.00 & 0.96 & 18.77 & 1.43 \\
\hline$T_{6}$ & 181.67 & 2.94 & 2.80 & 8.03 & 21.07 & 0.97 & 18.90 & 1.50 \\
\hline $\mathbf{T}_{7}$ & 174.67 & 2.80 & 2.64 & 7.77 & 21.30 & 0.87 & 17.20 & 1.40 \\
\hline $\mathbf{T}_{8}$ & 182.67 & 2.83 & 2.77 & 7.93 & 21.70 & 0.95 & 19.13 & 1.40 \\
\hline $\mathbf{T}_{9}$ & 187.00 & 2.83 & 2.82 & 8.24 & 21.93 & 0.94 & 19.17 & 1.47 \\
\hline $\mathbf{T}_{10}$ & 177.33 & 2.96 & 2.83 & 8.00 & 21.37 & 0.92 & 18.33 & 1.37 \\
\hline$T_{11}$ & 195.00 & 3.13 & 2.97 & 9.29 & 23.23 & 0.97 & 20.90 & 1.63 \\
\hline$T_{12}$ & 204.00 & 3.17 & 3.00 & 9.32 & 23.50 & 0.97 & 20.67 & 1.70 \\
\hline S.Em. \pm & 6.38 & 0.39 & 0.08 & 0.08 & 0.29 & 0.025 & 0.37 & 0.08 \\
\hline C.D. at $5 \%$ & 18.63 & 1.13 & 0.24 & 0.25 & 0.84 & NS & 1.07 & 0.24 \\
\hline
\end{tabular}

Table.2 Effect of pre-harvest spray of NAA, $\mathrm{KNO}_{3}$ and $\mathrm{ZnSO}_{4}$ on chemical and yield attributes in ber.

\begin{tabular}{|c|c|c|c|c|c|c|c|c|c|c|}
\hline Treatments & $\begin{array}{c}\text { TSS } \\
\left({ }^{0} \text { brix }\right)\end{array}$ & $\begin{array}{c}\text { Acidity } \\
(\%)\end{array}$ & $\begin{array}{l}\text { TSS/Acid } \\
\text { ratio }\end{array}$ & $\begin{array}{c}\text { Ascorbic } \\
\text { acid }\end{array}$ & $\begin{array}{c}\text { Reducing } \\
\text { sugar }(\%)\end{array}$ & $\begin{array}{c}\text { Total sugars } \\
(\%)\end{array}$ & $\begin{array}{c}\text { Non- } \\
\text { reducing } \\
\text { sugar }(\%)\end{array}$ & $\begin{array}{l}\text { Number of } \\
\text { Fruit/tree }\end{array}$ & $\begin{array}{l}\text { Fruit weight } \\
\text { (g) }\end{array}$ & Yield/tree (kg) \\
\hline $\mathbf{T}_{0}$ & 12.87 & 0.40 & 32.42 & 39.40 & 5.45 & 9.95 & 4.50 & 1405.67 & 17.13 & 24.09 \\
\hline $\mathbf{T}_{1}$ & 13.87 & 0.37 & 37.74 & 44.25 & 5.62 & 10.60 & 4.98 & 1460.00 & 18.57 & 27.10 \\
\hline $\mathbf{T}_{2}$ & 14.33 & 0.37 & 38.86 & 44.98 & 5.82 & 10.79 & 4.98 & 1563.33 & 21.10 & 32.99 \\
\hline $\mathbf{T}_{\mathbf{3}}$ & 14.50 & 0.33 & 43.68 & 45.00 & 5.86 & 10.89 & 5.03 & 1595.67 & 21.40 & 34.15 \\
\hline $\mathbf{T}_{4}$ & 13.53 & 0.32 & 42.98 & 41.23 & 5.57 & 10.30 & 4.74 & 1415.00 & 18.87 & 26.70 \\
\hline $\mathbf{T}_{5}$ & 13.93 & 0.31 & 44.79 & 42.33 & 5.67 & 10.65 & 4.98 & 1486.00 & 20.20 & 30.02 \\
\hline$T_{6}$ & 13.57 & 0.33 & 41.45 & 43.90 & 5.68 & 10.46 & 4.78 & 1496.00 & 20.40 & 30.51 \\
\hline $\mathbf{T}_{7}$ & 13.27 & 0.37 & 40.02 & 41.57 & 5.52 & 10.09 & 4.64 & 1441.00 & 18.60 & 26.79 \\
\hline $\mathbf{T}_{8}$ & 13.73 & 0.35 & 39.33 & 42.03 & 5.65 & 10.49 & 4.91 & 1521.67 & 20.53 & 31.21 \\
\hline $\mathbf{T}_{9}$ & 13.80 & 0.32 & 36.68 & 42.47 & 5.87 & 10.31 & 4.49 & 1531.00 & 20.63 & 31.57 \\
\hline $\mathbf{T}_{10}$ & 15.43 & 0.28 & 54.85 & 47.30 & 5.99 & 11.56 & 5.56 & 1570.67 & 19.70 & 30.92 \\
\hline $\mathbf{T}_{11}$ & 15.57 & 0.27 & 58.88 & 48.50 & 6.06 & 11.60 & 5.54 & 1577.33 & 22.53 & 35.55 \\
\hline$T_{12}$ & 15.93 & 0.26 & 61.06 & 49.47 & 6.11 & 11.87 & 5.76 & 1608.33 & 22.87 & 36.79 \\
\hline S.Em. \pm & 0.50 & 0.02 & 2.12 & 1.62 & 0.11 & 0.14 & 0.12 & 15.97 & 0.36 & 0.54 \\
\hline C.D. at $5 \%$ & 1.46 & 0.07 & 6.19 & 4.72 & 0.32 & 0.41 & 0.36 & 46.61 & 1.06 & 1.57 \\
\hline
\end{tabular}


Under the influence of chemicals, the acids might have been quickly converted into sugar and its derivatives by the reactions involving reversal of glycolytic pathway. These results are agreement with the findings of Singh et al., (1982), Singh et al., (1989), Kale et al., (1999), Bhati and Yadav (2003) and Kher et $a l .$, (2005) in guava, also reported an increase in sugars.

This increase in ascorbic acid content may have resulted owing to enhance synthesis of ascorbic acid, due to favorable metabolic activity involving certain enzymes and metallic ions under the influence of plant growth regulators and micronutrients. An Increase in ascorbic acid content might be due to perpetual synthesis of glucose-6-phosphate throughout the growth and development of fruits which is thought to be the precursor of vitamin C (Bhati and Yadav, 2003). The application of potassium results an increase in ascorbic acid content in ber cv. Gola. Rathore and Chandra (2002) in ber cv. Gola.

\section{Yield parameters}

The yield parameters of ber were significantly influenced by the NAA, $\mathrm{KNO}_{3}$ and $\mathrm{ZnSO}_{4}$. The maximum average fruit weight $(22.87 \mathrm{~g})$, maximum number of fruits per tree (1608.33) and highest yield per tree $(36.79 \mathrm{~kg})$ were noted recorded with the application of $\mathrm{T}_{12}$ (NAA $60 \mathrm{ppm}+\mathrm{KNO}_{3}+\mathrm{ZnSO}_{4} 0.5 \%$ ) which were significantly superior to the remaining treatment. The lowest yield parameters were recorded under control treatment may be due to lack of supply of nutrients (Table 2).

Increase in fruit weight may be attributed to the strengthening of middle lamella and consequently cell wall, which later may have increase the free passage of solutes to the fruits. This might have lead to more length and diameter of fruit and also larger weight of individual fruit. There was a positive and significant correlation between the length of fruit and weight of fruit and the diameter of fruit with weight of fruit. The increase in yield per plant is obviously due to the increase in volume and weight of fruit with the combined application of $\mathrm{NAA}, \mathrm{KNO}_{3}$ and $\mathrm{ZnSO}_{4}$. These results are in accordance with findings of Singh et al., (2001), Singh and Randhawa (2001) and Bhati and Yadav (2004) in ber.

In conclusion, the results of present experiment conducted on 6 years old ber cv. Seb plants showed that the Treatment $\mathrm{T}_{11}$ (NAA $40 \mathrm{ppm}+\mathrm{KNO}_{3} 1.0 \%+\mathrm{ZnSO}_{4} 0.4 \%$ ) was found most appropriate dose of NAA, $\mathrm{KNO}_{3}$ and $\mathrm{ZnSO}_{4}$ under agro-climatic conditions of Malwa plateau after the treatment $\mathrm{T}_{12}$ (NAA $60 \mathrm{ppm}+\mathrm{KNO}_{3} 1.5 \%+$ $\mathrm{ZnSO}_{4} \quad 0.5 \%$ ) for obtaining maximum vegetative growth and yield, improving the physical characteristics and quality of the fruit and it has also given maximum gross income. The treatment $\mathrm{T}_{3}$ (NAA $60 \mathrm{ppm}$ ) has given maximum net income (Rs. 73292.04) and maximum cost: benefit $(\mathrm{C}: \mathrm{B})$ ratio (1:3.40) which is economically viable as compare to other treatments.

\section{References}

Bal, J.S. and Randhawa, J.S. 2007. Effect of NAA on fruit drop and quality of Ber. Haryana J. Hortic. Sci. 36(3\&4): 231232.

Bal, J.S., Singh, S.N., Randhwa, J.S. and Jawanda, J.S. 1984. Effect of growth regulator on fruit drop, size and quality of ber. Indian J. Hort., 41(3-4): 182185.

Bankar, G.S. and Prasad, R.N. 1990. Effect of gibberellic acid and NAA on fruit set and quality of fruit in ber cv. Gola. Prog. Hort. 22(1-4): 60-62.

Barche, S., Kirad, K., Singh, K., Singh, V. K. and Singh, D. B. 2007. National 
Seminar on Recent Advances in Production, Protection and Post Harvest Management of Grape, Mandarin and Arid Fruits.94-96.

Bhati, B. S. and Yadav, P. K. 2003. Effect of foliar application of urea and NAA on the quality of ber (Zizyphus mauritiana Lamk.) cv. Gola. Haryana Journal of Horticultural Sciences 32: 32-33.

Bhati, B. S. and Yadav, P. K. 2004. Effect of foliar application of urea and NAA on the yield parameters of ber (Zizyphus mauritiana Lamk.) cv. Gola. Haryana Journal of Hort. Sci. 33: 189-190.

Grewal, S.S.; Singh, G.; Dhollon, W.S. and Singh, G. 1993. Effect of growth regulators on fruit drop and quality of fruit in ber (Zizyphus mauritiana Lamk.). Panjab Horti. J. 33 (1-2) 7683.

Iqbal, M., Khan, M.Q., Jalal-ud-Din., Khalid, R. and Munir, M. 2009. Effect of foliar application of NAA on fruit drop, yield and physico-chemical characteristics of guava (Psidium guajava L.) redflesh cultivar. J. Agri. Res. 47(3): 259-269.

Jain, M.C. and Dashora, L.K. (2007). Growth, flowerin, fruting and yield of guava (Psidium guajava L.) cv. Sardar as influenced by various plant growth regulators. J. Agric Sci. 3(1): 4-7

Kale, V.S., Dod, V.N., Adpawar, R.M. and Bharad, S.G. 2000. Effect of plant growth regulators on fruit characters and quality of ber (Zizyphus mauritiana L.). Crop Research (Hisar). 20(2): 327 333.

Kale, V.S., Kale, P.B. and Adpawar, R.W. 1999. Effect of plant growth regulators on fruit yield and quality of ber cv. Umran. Ann. Plant physi., 13(1): 69-72.

Kher, R., Bhat, S. and Wali, V.K. 2005. Effect of application of $\mathrm{GA}_{3}$, NAA and $\mathrm{CCC}$ on physic chemical characteristics of guava cv. Sardar. Haryana J. Sci. 34 (1-2): 31-32.
Kunda, S. and Mitra, S. K. 1999. Response of guava to foliar spray of copper, boron and zinc. Indian Agric., 43(1-2): 49-54.

Lal, G. and Dhaka, R.S. 2003. Effect of phosphorus and potassium fertilization on growth and yield of ber (Zizyphus mauritiana Lamk.) cv. Umran. Hamdard Medicus. 46(4): 80-81.

Masalkar, S.D. and Wavhal, K.N. (1991). Effect of various growth regulators on physico-chemical properties of ber cv. Umran. Maharastra J. Horti., 5 (2):3740.

Morton, J. 1987. Fruits of warm climates. Julia F. Morton, Miami, FL. pp.272275.

Pandey, V. 1999. Effect of NAA and $\mathrm{GA}_{3}$ spray on fruie retention, growth, yield and quality of ber (Ziziphus mauritiana Lamk.) cv. Banarasi Karaka. Orissa J. Hort. 27 (1):69-73.

Prakash K. and Balakrishnan S. 2014. Effect of Foliar Application of Some Chemical Substances on Fruit Characters of Pomegranate (Punica granatum L.) cv. Bahgwa. Trends in Biosciences 7(21): 3500-3501

Ramezani, S. and Shekafandeh, A. 2011. Influence of $\mathrm{Zn}$ and $\mathrm{K}$ Sprays on Fruit and Pulp Growth in Olive (Olea europaea L.) cv. Amygdalifolia Iran Agricultural Research, 30(1\&2): 1-10.

Rathore, R.S. and Chandra, A. (2002). Effect of application of nitrogen in combination with Zinc Sulphate on nutrient content, quality and yield ofber (Zizyphus mauritiana Lamk.) cv. Gola Orissa J. Hort., 30(1): 46-50.

Rathore, D.S. 1975. Deblossoming in rainy season crop guava by NAA. Prog. Hort. 7: 63-65.

Saroliya, D.K., Rathore, N.S. and Rathore, R.S. 2007. Response of zinc sulphate and iron sulphate spray on growth and production of Guava (Psidium guajava L.)cv. Sardar. Cuir Agric. 31(1-2): 73- 
77.

Singh, A.K., Singh, B.P. and Ram, R.B. 1982. Effect of gibberellic acid on physico and chemical characters of ber fruit $(Z$. mauritiana L.) Bangadesh Hort., 10(1): 47-49.

Singh, A.R., Shukla, P.K. and Singh, K. 1989. Effect of boron, zinc and NAA on chemical composition and metabolites of ber (Z. mauritiana Lamk.). Haryana J. Hort., 18 (1-2): 23-28.

Singh, O. 1988. Effect of calcium nitrate and plant growth regulators on nutrient uptake by leaves and fruit quality of guava (Psidium guajava L.). Prog. Hort., 20(3-4): 241-245.

Singh, R., Godara, N.R., Singh, R. and Dahiya, S.S. 2001. Responses of foliar application of growth regulators and nutrients in ber (Zizyphus mauritiana Lamk.) cv. Umran. Haryana Journal of Horticultural Sciences. 30(3/4): 161164.
Singh, R.V. 1973. Studies on the effect of alpha NAA, 2, 4-D and 2, 4, 5-T on fruit drop, fruit growth and quality of ber ( $Z$. mauritiana Lamk.). Thesis submitted to Kanpur University for M.sc. (Ag.) degree in Horticulture.

Singh, Kanwarjit and Randhawa, J. S. 2001. Effect of Growth Regulators and Fungicides on Fruit Drop, Yield and Quality of Fruit in Ber CV. Umran. Journal of Research, 38(3-4): 181-185

Yadav, B. 2002. Studies on the effect on NAA, urea and zinc on fruit drop, yield and quality of ber ( $Z$. mauritiana Lamk.) cv. Umran. M.Sc. Thesis, CCS Haryana Agricultural University, Hisar.

Yadav, D.N. and Chaturvedi, O.P. 2004. Influence ofGA3 and trace elements on fruit drop, growth and quality ofBer (Zizyphus mauritiana Lamk.) cv. Banarsi Karaka. Farm Sci. J., 14(1): 2728.

\section{How to cite this article:}

Gami, J., P. Sonkar, A. Haldar and Patidar, D.K. 2019. Effect of Pre harvest Spray of ZnSO4, KNO3 and NAA on Growth, Yield and Quality of Ber (Zizyphus mauritiana Lamk.) cv. Seb under Malwa Plateau Conditions. Int.J.Curr.Microbiol.App.Sci. 8(03): 1977-1984. doi: https://doi.org/10.20546/ijcmas.2019.803.235 